\title{
A invenção da representação: breve reflexão sobre a noção de representação
}

\author{
Bernardo Fonseca Machado
}

\begin{abstract}
resumo A noção de representação é um tema caro à antropologia. Pretendo contribuir, de maneira singela, para a discussão sobre o assunto valendo-me de perspectivas oriundas de áreas diversas, tentando estabelecer um diálogo entre as mesmas. A teoria teatral, a historiografia helênica e a antropologia contemporânea são as grandes áreas que servem de mote para a reflexão. $\mathrm{Na}$ teoria teatral contemporânea vemos um debate entre ensaístas que buscam pensar os espetáculos não mais como representações miméticas da realidade, mas como experiências cênicas. Valho-me de alguns historiadores, mais especificamente dois helenistas, para refletir sobre os modos de representação no mundo grego e, a partir deles, compreender o que esses modos dizem sobre nós Ocidentais. Por último, lanço mão da teoria de Roy Wagner para torcer os significados e pensar a representação sob outros termos.
\end{abstract}

palavras-chave Representação. Antropologia. Teoria Teatral. História. Experiência Social.

\section{Sete anos de azar?}

Suponhamos que um espelho se espatife no chão. Pensa-se logo, "sete anos de azar". E, em seguida, como se fosse uma reflexão espontânea, indaga-se "porque tal assertiva/maldição"? Diante dos cacos refletidos no chão pode-se perguntar: porque quebrar a imagem refletida, fragmentar a representação mimética, destruir a imagem do indivíduo diante de si pode "causar" sete anos de azar? E, desse modo, inicio meu pensamento.
Não se trata, agora, de uma compreensão histórica sobre o ditado "sete anos de azar", não seria capaz de fazê-lo - e provavelmente alguém muito melhor gabaritado, algum italiano cuidadoso ou francês dedicado já o tenha feito, isto é, analisado a origem desta superstição o que busco não é tampouco refletir - palavra com sentido diverso - sobre os variados significados da tal expressão. Assim, pretendo apenas lançá-la como mote, isto é, o que essa expressão pode contribuir para pensar como a noção de representação pode ser abordada sob diferentes perspectivas.

Náo busco dar conta de todas as vertentes - mais uma vez, náo sou gabaritado para tal apenas gostaria de lançar a questáo para certo autor da antropologia contemporânea, alguns ensaístas que tratam da noção de teatralidade e outros pesquisadores com ênfase histórica, de modo a compreender como pensam as maneiras de representação entre aqueles que podem ser denominados como os euro-americanos (para adotar o termo de Marilyn Strathern, 1987; 1992¹).

Voltando ao espelho quebrado, na cosmologia euro-americana tal objeto possui a "função" de "refletir" aquilo que está diante de si, apresentando um simulacro da "realidade". Por um lado, esse objeto reafirma a unicidade do indivíduo - ao olhar-se diante de si mesmo tem-se a certeza de sua particularidade -, por outro, ovaciona a possibilidade cognitiva de presentificação da "realidade" diante dos olhos - reflete aquilo que "é" o "real”.

Desse modo, o espelho valoriza a personalidade - para usar o termo no sentido dado por 
Roy Wagner $(2010)^{2}$-, destaca a representação - tema caro aos pensadores contemporâneos de teatro - além de ser objeto que presentifica a imitação da aparência - no sentido que dá Vernant (2009). Portanto, parto dessa metáfora e tento compreender como fazer render essas diferentes abordagens sobre representação. Entre teóricos do teatro vemos a preocupação em lidar com espetáculos que procuram se afastar da representação mimética da realidade, tentando criar não mais peças teatrais, mas experiências cênicas. De outro lado, também é possível fazer uma breve incursão histórica para mapear quais foram os modos de organização da representação no mundo grego (entre os séculos XII e IV a.C.) para compreender o que eles dizem sobre nós. Por último, lanço mão de Roy Wagner (2010) a fim de torcer a dita cosmologia euro-americana sobre como vemos a natureza e a cultura, apontando que aquilo que compreendemos como convenção não deixa de ser uma invenção.

\section{Teatro, teatralidade e representaçáo}

Há certo pressuposto quando se fala de teatro e sua relação com a representação. Muitas vezes espera-se que o teatro seja um dos modos da arte que "reproduz a realidade" ou a "torna evidente”. Essa percepção está associada àquilo que os teóricos teatrais chamam de teatro dramático realista ${ }^{3}$. Por exemplo, Peter Szondi, teórico de reconhecimento consagrado no campo da teoria sobre teatro ${ }^{4}$, aponta que a forma teatral do drama surgiu no Renascimento e representava a "audácia espiritual do homem que voltava a si depois da ruína da visão de mundo medieval, a audácia de construir (...) a realidade da obra na qual quis se determinar e espelhar." (Szondi, 2001, p.29).

Outro teórico teatral chamado Bernard Dort (1988, p.173) também aponta para certa tradição de encarar o teatro como o espaço da representação pela realidade.
O estatuto do teatro se dá de forma contraditória. É uma evidência que perdemos muitas vezes de vista. Fundado sobre a "mímesis", o teatro faz da ação uma ilusão e transforma, por vezes, essa ilusão em ação (tradução minha) $)^{5}$.

Diante disso, nota-se que apenas sob certo paradigma - aquele que entende o teatro dramático pós-renascimento como mote para pensar - compreende-se o teatro como "representação da realidade". As formas teatrais gregas, medievais e de origens diversas, como o teatro balinês, por exemplo, não tomam a representação como pressuposto para a produção artística, buscam outras formas de experiência ${ }^{6}$. No entanto, parte da cosmologia euro-americana contemporânea acaba por compreender o teatro naquele recorte histórico. A experiência social relativamente recente, que parte do renascimento e segue até a virada do século XIX para o XX, atesta tal compreensão.

Roy Wagner é um autor que pressupóe um certo teatro realista - preocupado com a representação da realidade - quando está falando da percepçáo da relatividade de um contexto ${ }^{7} \mathrm{e}$ acaba por utilizar como exemplo uma situação teatral específica.

Quaisquer que sejam as circunstâncias de sua ocorrência, a percepçáo da relatividade de um contexto de controle corresponde a um "desmascaramento" da invenção iminente e a um sentimento de que "algo está sendo feito" àqueles que dela participam. É esse sentimento que dispara a reação negativa, especialmente nos espectadores ou naqueles que participam na cena como ator. Eles se sentem vulneráveis e se tornam defensivos, desejam "combater" a influência ofensiva, e o que defendem é um certo modo convencional de percepção e ação (Wagner, 2010, p.101).

No entanto, há, como disse, outros modos de fazer teatro operantes, tanto ao longo da 
história, como nos dias que correm. A discussão sobre representação está presente e é tema de grande importância entre os pensadores teatrais contemporâneos, preocupados em observar novos paradigmas e estilos de produção teatral do final do século XX.

Bernard Dort (1988), Martin Puchner (2002), Josette Féral $(1985$; 1988) e Silvia Fernandes (2010) são alguns autores que, sob orientaçóes e perspectivas diferentes, tentam traçar teoricamente como as práticas teatrais contemporâneas estão produzindo espetáculos cuja relação não é mais de representação da realidade, pelo contrário, tentam proceder de outras formas.

Martin Puchner, por exemplo, estabelece a oposição entre o que chama de antiteatralidade e pró-teatralidade. A antiteatralidade seria a postura adotada por autores ${ }^{8}$ que suspeitam do teatro fundado sob três paradigmas: 1 - a representação do real (o teatro como representação mimética e reprodução da realidade); 2- a personagem (que seria o agente de reprodução mimético por excelência); e 3- a construção da narrativa. Por outro lado, entre aqueles que assumem a teatralidade como postura artística, os pró-teatralidade, haveria uma valorização tanto da reprodução do real, quanto da figura da personagem, quanto da narrativa lógica.

Segundo Puchner, não se trata de uma dicotomia estável, mas de uma ferramenta para analisar a variedade de posiçóes e fenômenos que se desenvolvem. A partir dos diálogos da República de Platão, o autor aponta a oposição frente à "arte do engano", dando ênfase ao fato de que mesmo na esfera grega havia uma certa suspeita quanto à representação da realidade.

O que importa destacar é como o autor apresenta o antagonismo entre os defensores da representação e aqueles que se opóem a ela. De acordo com Puchner, o antagonismo só adquire foros de luta estética (para utilizar a análise de Silvia Fernandes, 2010) a partir do modernismo, quando a representação da realidade é sustentada pela coerência concomitante da personagem com a ficção dramática. Há um ataque de autores antiteatrais, como Adorno, Benjamin, Brecht e Beckett, à representação:

O que eles [os críticos antiteatrais] tendem a contrariar é uma forma particular de trabalhar com mímesis no teatro, a mímesis causada pela difícil posiçâo do teatro entre uma arte performática e uma arte mimética. Como uma arte performática como a música ou o ballet, o teatro depende da aptidão do performer no palco. Como uma arte mimética, como a pintura e o cinema, por outro lado, ele precisa utilizar essa performance humana como material significante em serviço de um projeto mimético. Uma vez que a natureza da mímesi é submetida ao controle e ataca, tal como no modernismo, a afiliação dupla do teatro ela se torna um problema porque, ao contrário da pintura e do cinema, o teatro continua atado aos performers humanos, não importa quão estranhas suas atuaçóes possam ser (Puchner, 2002, p.5, tradução minha) ${ }^{9}$.

Desse modo, Puchner está chamando a atenção para certa "crise" do teatro moderno, que quer se afastar da representação mimética do mundo. De acordo com ele aquilo que denomina como "teatro moderno" alterou sua relaçáo com este modo de produção representacional a partir de novas concepçóes sobre o texto dramático, a concepção das personagens e o trabalho do ator. Exemplos desta busca pela mudança são o encenador Edward Gordon Craig, e os dramaturgos Bertold Brecht e Samuel Beckett. O primeiro, inglês da virada do século XIX para o XX, estava empenhado em recusar a personificação do ator nas personagens, de modo a defender um teatro abstrato, realizado por androides e supermarionetes. Bertold Brecht, por sua vez, é considerado um dos grandes dramaturgos da primeira metade do século XX justamente por apostar no distanciamento do ator em relação ao seu papel - o ator 
não poderia, em suas peças, se metamorfosear na personagem, mas deveria atuar sobre ela, com uma opinião política sobre aquilo que diz. Por último, em Beckett, a partir dos anos 1950, as situaçóes absurdas em que coloca as personagens, com diálogos entrecortados e esparsos, apresenta não uma representação mimética da realidade, mas elementos dilacerados e difusos - exemplo claro disso é a peça Esperando Godot.

Bernard Dort (1988), por sua vez, está preocupado em apontar que a mímesis e a representação teatral ao longo do século XIX e XX estariam em declínio, abrindo espaço para novas formas de teatralidade. Ele entende que há uma tendência contemporânea no fazer teatral que aposta em uma "representação emancipada”, distante tanto do texto quanto da mímesis. Silvia Fernandes (2010, p.120), lendo Dort, destaca:

A nova concepção de representação, especialmente dominante no teatro dos anos 70 e 80 do século passado, não postula a união das artes visando a um efeito comum, como na gesamtkustwerk wagneriana, mas defende a relativa independência das várias fontes de enunciação do teatro, que se deslocam e se confrontam ${ }^{10}$.

Fernandes também aponta a importância de encenadores, como Robert Wilson, no fazer teatral contemporâneo. Nas encenaçôes de Wilson valoriza-se a expansão do tempo, com falas rápidas ou dilatadas, a grande utilização de luzes variadas e gestos distintos. Por exemplo, na peça Quartett de Heiner Müller, apresentada entre 12 e 16 de setembro de 2009 no SESC Pinheiros em São Paulo, Bob Wilson utilizava um objeto cênico ondulado, do tamanho de uma mulher, que se remetia a um sofá andante no qual a personagem de Isabelle Hupert sentava-se e discorria um texto em grande velocidade e com grande variação tonal, enquanto um grande círculo 2D girava no cen- tro do palco, iluminado por uma luz entrecortada. O próprio Heiner Müller, no programa da peça, diz:

O ponto central do teatro do Bob é a igualdade dos elementos texto, luz, som, objetos de cena, atores. Isso é agradável, porque não ataca de nenhum jeito o texto: ele fica tratado do mesmo jeito como objeto e fato como o palco e como o mobiliário. Assim os textos ficam transparentes por todos os lados (Programa..., 2009).

Assim, chamo a atenção para a valorização, no teatro e na teoria contemporânea que trata sobre o teatro, da experiência ou da "teatralidade” cênica e não mais da representação mimética. Josette Féral é uma das teóricas que pode contribuir para essa reflexão. Utilizo-me de dois textos da autora para apresentar sua perspectiva sobre teatralidade e performance. No primeiro, de $1985^{11}$, intitulado "Performance et theatralité, le sujet desmistifié", a autora opóe os dois conceitos. Segundo ela, a performance se distingue da teatralidade porque se constitui como evento não repetível, apresentado no momento presente em um espaço indissoluvelmente ligado à proposta de criação. Trata-se de uma criação que procura evitar a ilustração, indicação ou simbolização.

Em um segundo texto, de $1988^{12}$, chamado "Theatricality: On the Specificity of Theatrical Language", Féral atenua a oposição anteriormente traçada e aponta que a performatividade é um dos elementos presentes na teatralidade. Para ela o teatro contemporâneo beneficiou-se amplamente de algumas conquistas da arte da performance, pois as práticas performativas teriam redefinido os parâmetros para pensar a arte. Voltando à Silvia Fernandes (2010, p.126), responsável por traçar uma grande síntese das teorias teatrais contemporâneas que discutem teatralidade e performance: 
Sem dúvida, as operaçôes performativas de produção e transformação cênica de situações são as maiores responsáveis pelo desvio paulatino das exigências da representação enquanto processo centrado na ilusão e no traçado ficcional, em proveito da ação cênica real e do acontecimento instantâneo e não repetível. Esse desvio determina outro tipo de endereçamento ao receptor, transformando o apelo puramente especular em encorajamento de percepçóes sensoriais, por meio do mergulho em experiências imersivas próprias às novas tecnologias. Segundo Féral, essa mutação cênica define uma ruptura epistemológica de tal ordem que é necessário adotar a expressão teatro performativo para qualificá-la.

Deste modo, aponto que estes teóricos estão chamando a atenção para espetáculos teatrais cuja encenação não busca a representação mimética da realidade, mas sim uma "experiência teatral”. Por outro lado, também apontam para o surgimento de novas práticas cênicas que valorizam a performance em lugar da história narrativa. Trata-se de uma nova configuração do fazer teatral que tenta afastar-se ao máximo do modo representacional de produzir espetáculos. Evidente que isso pode ser lido de diversos modos, por um lado, é uma forma de diferenciação no campo teatral (sob a ótica de autores como Bourdieu, 2005), por outro lado, isso também fala e informa sobre uma nova experiência social (para usar os termos de Baxandall, 1991) que se configurou e ainda se configura na cosmologia euro-americana.

Com a representação mimética não mais em pauta, interessa observar como os novos agentes produzem espetáculos ou mesmo performances que articulam com a experiência ${ }^{13}$.

Ao observar esse modelo de representação que vai sendo cunhado pelas práticas teatrais podemos traçar reflexóes acerca do modo como se pode entender a representação na experiência social que se configura e está configurada. Não mais o espelho como modo por excelência de pensar o mundo. $\mathrm{O}$ que isso quer dizer de nosso modo de compreensão?

Não quero, com essa pergunta ou com as reflexôes oriundas do pensamento teórico sobre o teatro, recair naquilo que Marilyn Strathern (1987) chama de confusão entre reflexividade e autoconsciência quando se faz a antropologia de nós mesmos ${ }^{14}$. O que me interessa é produzir uma reflexão a partir do choque de argumentos oriundos de diferentes áreas do conhecimento, talvez assim possa produzir um distanciamento relevante.

De acordo com Eduardo Viveiros de Castro (2002, p.114 e p.119, respectivamente):

(...) Ainda quando o antropólogo e nativo compartilham a mesma cultura, a relaçáo de sentido entre os dois discursos diferencia tal comunidade: a relaçáo do antropólogo com sua cultura e a do nativo com a dele não é exatamente a mesma. $\mathrm{O}$ que faz do nativo um nativo é a pressuposição, por parte do antropólogo, de que a relaçáo do primeiro com sua cultura é natural, isto é, intrínseca e espontânea, e, se possível, não reflexiva; melhor ainda se for inconsciente. $\mathrm{O}$ nativo exprime sua cultura em seu discurso; o antropólogo também, mas, se ele pretende ser outra coisa que um nativo, deve poder exprimir sua cultura culturalmente, isto é, reflexiva, condicional e consciente.

(...) O problema é que o nativo certamente pen$s a$, como o antropólogo; mas, muito provavelmente, ele não pensa como o antropólogo. (...) A boa diferença, ou diferença real, é entre o que pensa (ou faz) o nativo e o que o antropólogo pensa que (e faz com o que) o nativo pensa, e são esses dois pensamentos (ou fazeres) que se confrontam.

Nestes termos, Viveiros de Castro auxilia na exposição que procuro dar. Ao longo da pesquisa e do texto esforço-me por pensar e refletir sobre como os agentes pensam e como nós, 
euro-americanos, pensamos. Trata-se, como diz Strathern (1987), de conhecer nós mesmos tanto como objeto de estudo quanto como sujeitos que fazem o estudo - embora essas duas categorias estejam fundidas na mesma premissa cultural de que o conhecimento é uma espécie de autoconhecimento. A noção de autoconhecimento só pode vir de uma fórmula circular, isto é, a autoantropologia provém de uma cultura/ sociedade que detém em si o conceito de cultura/sociedade e na qual há a convenção de que é possível captar a cultura porque algo genuinamente está estático, há um ponto estável para a análise, há uma convenção estabelecida no qual o resto é tido como representação. Adiante, Roy Wagner (2010) torcerá essas mesmas premissas. Entretanto, cabe, antes, uma pequena digressão sobre o mundo grego.

\section{Histórias e mais história}

A fim de refletir sobre a representação e a performance no mundo contemporâneo, faço uma breve digressão sobre a experiência social grega, de modo a, quem sabe, fazer falar a história e seus ciclos de longa duração sobre nosso modo de compreender o "real".

Jean-Pierre Vernant no livro Entre Mito $e$ Politica (2009) escreve o artigo intitulado " $\mathrm{Da}$ presentificação do invisível à imitação da aparência”, nele esboça uma teoria sobre os modos de representação ${ }^{15}$ constituídos no mundo helênico. De acordo com o autor, a noção de representação figurada - isto é, a imagem como ponto por excelência de condensação daquilo que é representado - não pode ser tomada como óbvia ou evidente, mas sim percebida como categoria histórica, construção elaborada por vias variadas nas diversas civilizaçóes. $\mathrm{Na}$ virada dos séculos V e IV a.C. a teoria da mímesis, da imitação, esboçada por Xenofonte e elaborada por Platão, marca o momento em que, na cultura grega, o modelo de representação se altera, passa-se da presentificação do invisível para a imitação da aparência.

Aos gregos preocupava fazer ver o invisível e designar um lugar em nosso mundo às entidades do além, os deuses e os mortos. Pretendia-se inscrever a ausência em uma presença e o objeto escolhido para tal operação era o ídolo (o talismã). No entanto, tal estatuária não remetia a uma imagem física e mimética de um deus ou de um morto, o ídolo não era feito para ser visto, era feito para ser ritualizado, inseparável das operaçóes rituais que eram exercidas sobre ele. Trata-se de uma figura que necessita do rito para representar a potência e a ação divinas. Mas o símbolo não representa o deus, não procura instruir-nos sobre sua natureza, pelo contrário, expressa a potência divina enquanto manejada e utilizada por determinados indivíduos, como instrumento de prestígio, meio de domínio e de ação. Portanto, tratava-se de um modo de lidar com a representação na chave de presentificar o invisível, os deuses e mortos, em símbolos não figurados, mas rituais.

No entanto, com o surgimento das cidades gregas a experiência social se altera e é no advento destes núcleos que surge a noção de imagem como simulacro. O templo é consagrado aos deuses para ser sua residência e, nesse sentido, um caráter de publicidade se inscreve no fazer representacional. A estátua que surge é "representação" em um sentido novo. Livre do ritual e colocado sob o olhar impessoal da cidade, o símbolo divino transformou-se em "imagem" do deus. A noção de mímesis e simulacro ganha aqui genuíno poder.

A primeira lógica operante é a lógica das imagens rituais, há objetos de valor simbólico que não necessariamente figuram, mas que são sagrados porque investidos de valor sagrado, são ídolos e talismãs que contêm a divindade. $\mathrm{O}$ ídolo porta o divino de modo que sua relação é metonímica, o objeto contém o que 
quer representar. No entanto, as cidades surgem como o espaço que tem lugar novas formas de representação, são o local dos templos públicos - as novas moradas dos deuses, espaço para visibilidade - portanto imagem e templo precisam ter relações próximas. $\mathrm{O}$ corpo grego, perfeito e pleno, é aquele que poderá representar, como simulacro, a imagem dos deuses.

Estamos diante de duas formas, ou funçóes, da representação, a primeira como representação do invisível e a segunda como simulacro do visível. Ao final do artigo, Vernant deixa claro que não se trata de uma lógica evolucionista em que uma das formas sucede a outra, mas sim da observação de que ambas convivem, possuem idas e vindas históricas, variando a ênfase com que são tratadas. Dependendo da experiência social de uma época há preferência por um modo de representação em detrimento de outro.

Portanto, penso, são duas modalidades de representação que operam ainda hoje no modo de produzir arte. De um lado, tem-se o dito "teatro representacional" no qual o simulacro, a mímesis, a imagem reproduzida, marca as práticas e, de outro, tem-se a performance, como o "espaço genuíno" para a "experiência verdadeira”, em que se produz uma representação do invisível e tem-se uma dimensão ritual. A representação, em Vernant, assume dimensão histórica, compreendemos objetos e relaçóes miméticas a partir da experiência social grega.

Diante disso, pode-se torcer o argumento sob outra ótica. Segundo François Hartog (1999), outro helenista, "descrever é ver e fazer ver". Interessado em mostrar como as narrativas de viagem gregas permitiam uma consideração detida sobre a retórica da alteridade, Hartog apresenta um argumento que valoriza a descrição como um modo de "fazer ver" o mundo.

Observando as descriçóes das epopeias gregas o autor indica o privilégio que o olho tem sobre a constituição do conhecimento. A visão é tida como o sentido que produz o conhecimen- to mais preciso, mais distinto, seria, portanto, o sentido que faria melhor ver as diferenças. Ver constitui o saber. Para fazer o outro ver aquilo que $o$ sujeito viu é preciso descrever. Esta seria a herança que comungamos com os gregos.

Hartog (1999, p.263) recorre às descriçóes elaboradas por Herótodo, o dito primeiro historiador grego $^{16}$, para tratar de tal questão:

Nem Herótodo nem Léry são escritores natu-
ralistas, mas é inegável que, num e noutro, as
descriçóes têm a ver com a taxionomia. Pode-se
então tirar a primeira conclusão disso: a descrição
é ver e fazer ver, mas, desde o momento em que
se articulam espaço e saber, em que ela é espacia-
lização de um saber, em resumo, um quadro - a
descrição vem a ser também saber e fazer saber
[...].

Hartog continua apresentando Herótodo como aquele no qual não existe nenhuma distância entre dizer e ver, ver e dizer, visível e dizível comunicam-se plenamente ou, sobretudo, não são constituídos como esferas separadas. Desse modo, o que se diz daquilo que se viu parece representação direta, real, objetiva. Interessante pensar que o dito "primeiro historiador" ocidental pauta suas narrativas em descriçóes cujo fundamento é o "eu vi". Embora ao longo de quase vinte séculos diversas críticas tenham sido elaboradas contra Herótodo e seu modo de descrição - chamam-no mentiroso e ficcional -, no século XVI há a retomada de sua produção, deixando de ser encarada como mentira. Importa pensar que as formas de narrativa, pautadas pela descrição, não deixam de ser o modo genuíno de produção da história e, portanto, modos de representação de seu contexto, ou maneira de representação do outro.

O que é a antropologia senão uma descrição, ou uma representaçáo sobre o outro ${ }^{17}$ Representar, desse modo, assume duas características: primeiro, a representação como modo de obje- 
tificação da figura de um deus, tal como alertava Vernant - desse estilo deriva a representação mimética que pauta o teatro dramático realista pós-renascimento; segundo, representação como modo de descrição do mundo, maneira elaborada de organizar aquilo que se vê e arregimentar em uma história, tal como aponta Hartog. Nós, os ditos euro-americanos, estaríamos imbuídos de ambos os modelos de representação em nossas práticas, cabe agora, a Roy Wagner, a análise sobre esse modo particular de invenção.

\section{Invenção, convenção e representação}

Roy Wagner é o autor que torce os significados e os modelos de abordagem da antropologia de modo específico, trazendo à baila da discussão uma composição complexa e peculiar de encarar as diferentes culturas. Seu argumento está centrado na discussão entre o reino daquilo que seria considerado inato, ou "dado", e o reino daquilo que os seres humanos consideram poder assumir controle ou responsabilidade. Esses dois reinos, afirma Wagner, não são necessariamente os mesmos de uma cultura para outra e seu interesse reside justamente em apresentar a configuração desses reinos em diferentes culturas. Importa refletir as maneiras como são representados e as maneiras pelas quais são transcendidos ou subvertidos - é isto que o autor denomina como "invenção da cultura".

Segundo tal perspectiva, os fenômenos sociais ou culturais podem ser vistos como uma série de interações dialéticas entre a "convenção" e a "invenção" - cuja relação se dá em séries de reversôes entre figura/fundo, isto é, a convenção e a invenção alteram-se no próprio ato de observação do sujeito que observa - é necessária a "restrição da visão, concentrando a percepção consciente e a intenção do ator em um dos modos e em seu efeito." (Wagner, Op. cit., p.86). $\mathrm{O}$ que há de convenção só pode ser visto em contraste com aquilo que é invenção, e a invenção só pode ser vislumbrada em contraste com aquilo que é convenção.

Sob a égide desse projeto da "invenção da cultura”, Wagner traça uma discussão acerca dos modos de representação e simbolização de sua sociedade e suscita questóes interessantes para pensar o assunto. A tese central do argumento encontra-se no capítulo três do livro $A$ invenção da Cultura (2010), intitulado "O poder da invenção". Nele a noção de contexto e dos mecanismos de produção simbólica da convençáo e da invenção são detalhadamente trabalhados.

Wagner aposta no caráter simbólico de produção de significados em todas as culturas, no entanto, esclarece que "não aspiro (a não ser conceitualmente talvez) a uma 'linguagem' que falaria sobre símbolos (...)" (Wagner, Op. cit., p.23). Descarta, nesse sentido, a possibilidade de uma "ciência dos símbolos" justamente porque entende que símbolos e pessoas existem em uma relação de mediação mútua, uma compondo a outra, produto e produtoras simultâneas ${ }^{18}$. Em seus termos, o que se tem é um conjunto de ordenamentos e articulaçóes que a ação representa para nós em termos absolutos: inato e artificial, convencional e não convencionalizado. Isto é, símbolos que variam entre invenção e convenção. Portanto, descarta a existência de algum "mecanismo" fixo no interior da mente humana ou algum tipo de "estrutura" superorgânica imposta ao homem (afasta-se simultaneamente de Lévi-Strauss e Durkheim).

A fim de compreender a dimensão que Wagner postula para a simbolização - e a partir dela poder analisar como ele colabora para pensar a noção de representaçâo - é preciso fazer uma breve reconstrução da noção de contexto em sua obra.

Um contexto, segundo o autor, é uma parte da experiência, como também algo que nossa própria experiência constrói, isto é, trata-se de um ambiente no interior do qual elementos sim- 
bólicos se relacionam entre si e cuja formação se dá pelo próprio ato de relacioná-los. Compreende-se que os contextos são ambientes nos quais tais elementos simbólicos podem estar envolvidos e relacionados.

Nesses termos, há certas associações compartilhadas que servem para relacionar as qualidades significativas da expressão (no sentido de comunicação) com as orientaçóes dos atores que se comunicam. Trata-se de um arcabouço simbólico relacional no qual as possibilidades de comunicação entre os humanos se tornam possíveis.

Entretanto, esses mesmos contextos podem ser mais ou menos convencionais - os contextos mais convencionais parecem tão familiares que os percebemos como todos, coisas ou experiências em si mesmos - entretanto, tais contextos nunca são absolutamente convencionalizados, são incompletamente compartilhados e estão em constante processo de mudança.

De acordo com Wagner, os vários contextos de uma cultura obtêm suas características significativas uns dos outros, por meio da participação de elementos simbólicos em mais de um contexto. Eles são inventados uns a partir dos outros e a ideia de que certos elementos simbólicos ou mesmo contextos inteiros são "inatos" ou "essenciais" é uma ilusão cultural - que não deixa de ser necessária e faz parte do modo de viver em uma cultura e de inventá-la de dentro. Portanto, a nossa noção de "natureza inata" ou "realidade apreensível" está pautada de acordo com essa nossa invenção. Os elementos simbólicos de nossa cultura arregimentaram-se de modo a constituir esta ilusão peculiar - presente dentro desse ambiente simbólico nosso, dentro de nosso contexto.

Entrementes, o autor apresenta uma outra operação fundamental para a compreensão da articulação dos contextos, trata-se daquilo que chama como "mascaramento convencional". De acordo com Wagner, o mascaramento nada mais é do que o condicionamento de nossa percepção consciente pela propriedade de autoabstração dos símbolos convencionais. Nossa cultura, nesse sentido, mascara a invenção de uma natureza inata, de uma realidade exterior. Tal mascaramento convencional é sempre estendido e recriado como parte da operação da própria invenção, está implícito, nos termos de Wagner, nos próprios contextos convencionais, na medida em que eles são inventados ou contra inventados.

Retornando ao argumento central, invenção e convenção são de importância crucial para a apreensão da ação e do mundo da ação.

Sem invenção, o mundo da convenção, com sua táo importante distinçáo interpretativa entre o 'inato' e o 'artificial', não poderia ser levado adiante. Mas sem as distinçôes convencionais, que orientam o ator em seu mundo, que lhe dizem quem ele é o que pode fazer e desse modo conferem a seus atos um mascaramento convencional e uma motivaçáo convencional, a invenção seria impossível (Wagner, Op. cit., p.95).

Por um lado, a convenção integra um ato na coletividade e serve ao propósito de traçar distinçôes coletivas entre o inato e o reino da ação humana, por outro lado, a invenção tem o efeito de continuamente diferenciar ator e eventos daquilo que é convencional, especificando e delineando individualidades.

Uma simbolização convencional objetifica seu contexto díspar ao conferir-lhe ordem e integração racional; uma simbolização diferenciante especifíca e concretiza o mundo convencional ao traçar distinçóes radicais e delinear suas individualidades (Wagner, Op. cit., p.86).

A dialética cultural, por último, inclui ambas as operações, é o universo em que distinçôes são integradas (invenções tornam-se convenções) e integrações são distinguidas (convenções 
tornam-se invençóes), reúne e distingue pessoas, combina contextos inatos e artificiais de maneiras originais e altamente específicas ${ }^{19}$. Nesses termos, fica claro por que Wagner determina um subtítulo sob o nome de "A Necessidade da Invenção", é evidente que sua aposta se dá no caráter generalizado desse procedimento de invenção e convenção entre todas as culturas humanas existentes. No entanto, nós Ocidentais possuímos certa peculiaridade.

Segundo Wagner, como as ênfases entre convenção e invenção se alteram e apresentam um mundo no qual há variação entre aquilo que é inato e o que é artificial, não há, em última instância, uma "realidade" exterior a ser captada e representada. A própria noção de "representação" apareceria reformulada haja vista que todas as formas de capitulação humana derivariam desse procedimento de ordenações e articulações de ação simbólica, a própria noção daquilo que é inato é derivação desses procedimentos. $\mathrm{O}$ inato é constituído e o artificial também, o que varia seriam as escolhas daquilo que é convenção e o que é invenção em cada constituição cultural.

O que há é um certo "mascaramento convencional", nos termos de Wagner, sobre aquilo que é produzido como convenção. Nossa articulação consciente acaba por mascarar a invenção de uma natureza inata e motivadora, uma realidade exterior e maior. A noção de representação estaria, e aqui a afirmação é minha, impregnada desse mascaramento, seria ela própria uma das suas formas de operação. Dizer que representamos a natureza ou a realidade é uma das formas de reiterar nossa autoimagem de que não produzimos a natureza como inata, mas que ela existe per se para além de nossos domínios. Nossa própria noção de representação reitera e supóe o inato a ser representado, de forma que a operação difundida de representação é mecanismo operador do próprio mascaramento convencional. Ao contrastar esse nosso modo de ordenação com outros povos tribais - tal como o faz Wagner
- pode-se genuinamente apreender nosso procedimento de atuação de modo a colocá-lo sob outra perspectiva, apresentando-o como uma das possibilidades de arranjo entre a convenção e a invenção.

E aqui aprofundamos os argumentos lançados anteriormente. Também faz parte de nossa invenção cultural convencionalizar e coletivizar. Entendendo a convenção como elemento construído, para nós a diferenciação é um dado todos os indivíduos são entendidos como seres diferentes, o que precisa ser construído é o coletivo, a convenção - ao passo que entre os Daribi (este é o exemplo de Wagner) há a tendência pela diferenciação, ela precisa ser constituída a todo momento, ao passo que a convenção é tida como algo inato. Nós, os euro-americanos, estamos a todo instante querendo objetificar, construir sobre o que há de inato, as diferenças presentes devem ser coletivizadas, "a realidade" precisaria se arregimentar, queremos criar entidades homogêneas. Uma representação teatral calcada na "realidade" seria uma forma de produzir uma entidade homogênea.

Entretanto, e agora começo a misturar tudo, vemos que a experiência social aparentemente se alterou e hoje se indica, no fazer teatral, não mais a busca por uma objetificação, ou coletivização da realidade em uma obra única e absoluta. Interessa, pelo contrário, uma obra singular, baseada em diferenças, em incongruências, em fluxos. Não estou dizendo que deixamos de coletivizar, mas chamo a atenção para um aspecto de nossa cosmologia no qual a diferenciação começa a tomar novas proporçóes.

Estamos diante de duas camadas de observação. No primeiro plano nós, do dito Ocidente moderno, continuamos a pensar a convençáo como algo construído, é nossa intenção coletivizar e criar regras, o indivíduo ainda é tido como inato, possui a sua subjetividade dada, somos diferentes naturalmente. No segundo plano, o teatro contemporâneo, com sua busca pela per- 
formance, reitera o primeiro plano - o indivíduo ainda é o fruto natural da diferença - mas não se busca mais uma representação que coletivize tudo, o que interessa são os ditos "híbridos", a "experiência em fluxo". Trata-se de um momento em que a experiência social deixa visível algo que Roy Wagner anunciava: quanto mais apontamos categorizaçôes, objetificações, mais vemos as diferenças, mais reinventamos.

\section{Últimas reflexóes}

É inevitável especular sobre a possível diluição do estatuto da representação nessa situação de turbulência expressiva. Pois parece claro que um teatro de vivências e situaçóes públicas não pretende apenas representar alguma coisa que não esteja ali. A impressão que se tem é de uma tentativa de escapar do território específico da reprodução da realidade para tentar a anexação dela, ou melhor, ensaiar sua presentação, se possível, sem mediaçóes. Nesse movimento, o que parece evidente é a dificuldade de dar forma estética a uma realidade traumática, a um estado público que está além das possibilidades de representação, e por isso, entra em cena como resíduo, como presença performativa na teatralidade, indicando algo que não pode ser totalmente recuperado pela simbolização.

Com esse trecho de Silvia Fernandes (2010, p.128) levanto duas questóes. Primeiro, parece que a suposição de uma realidade a ser representada e convencionalizada, construída em cena, deixou de fazer sentido para certos produtores teatrais contemporâneos. Segundo, ainda assim há, como suposto, a presença de uma realidade que pode ser apreendida sem mediação, como um suporte que pode ser experimentado, mas não mais pela dimensão da objetificação, mas pela diferenciação. O performer é aquele indivíduo que diferencia - a partir de seu eu inato -, mas que não convencionaliza, deixa a experiência como fluxo diante da plateia - nosso processo de coletivização continua sendo construído, mas deixa de ser o objetivo primordial do trabalho estético teatral. Trata-se de mudança pequena, mas que pode assumir caráter interessante na análise.

O estudo ou representação de uma outra cultura não consiste numa mera "descriçâo" do objeto, do mesmo modo que a pintura não meramente "descreve" aquilo que figura. Em ambos os casos há uma simbolização que está conectada com a intenção inicial do antropólogo ou do artista de representar o seu objeto. (...) O que o pesquisador de campo inventa, portanto, é seu próprio entendimento: as analogias que ele cria são extensôes das suas próprias noçóes e daquelas de sua cultura, transformadas por suas experiências da situação de campo. (...) O efeito dessa invenção é táo profundo quanto inconsciente; cria-se o objeto no ato de tentar representá-lo mais objetivamente e ao mesmo tempo se criam (por meio de extensão analógica) as ideias e formas por meio das quais ele é inventado. O "controle", seja o modelo do artista ou a cultura estudada, força o representador a corresponder às impressóes que tem sobre ele, e no entanto essas impressóes se alteram à medida que ele se vê mais e mais absorto em sua tarefa (Wagner, 2010, p.40-41).

Como separamos os símbolos das coisas imaginamos um mundo distante, isolado, que podemos apreender pela representação. Roy Wagner tece um diagnóstico: vivemos em uma esquizofrenia contínua, separamos em demasia o reino do inato - a natureza - do reino do construído - a cultura - quanto mais quisermos convencionalizar o que é diferenciante criamos uma cultura interpretativa que relativiza tudo. A mim parece que no reino do inato alocamos a dita "realidade" e no reino do construído chamamos de "representação". Se as produções teatrais esti- 
verem tratando de algo interessante vemos que essa separação tão explícita deixa de fazer sentido. Há uma experiência social distinta se configurando, ao menos essa é minha aposta, uma experiência próxima à representação dos ídolos que Vernant chamava atenção, uma representação na qual a "experiência" faz-se mais presente e necessária (os híbridos estão pulando, como diria Latour, $2009^{20}$ ). Pode ser apenas impressão equivocada, mas está é a leitura que proponho.

Se Roy Wagner está preocupado em traçar uma observaçáo que verse sobre as formas de invenção da sociedade Ocidental (ou euro-americana), os historiadores como Vernant e Hartog pretendem traçar uma história de longa duração sobre os modos de representação que atravessaram as diferentes experiências sociais do que pode se entender como Ocidente, e, por último, autores como Martin Puchner, Bernard Dort, Josette Féral e Silvia Fernandes, na área teatral, estão interessados em ver como a representação deixa de fazer sentido em certas áreas da estética e valorizam o fazer performático ou teatralizado de arte.

Diante de tudo o que foi apresentado, reitero que as formas de representação euro-americanas tiveram certa organização registrada na Grécia antiga e começaram a ser pautadas pela relação entre a figura e simulacro. Ao longo da história do teatro podemos vislumbrar esse recurso operante, a "representação da realidade" como modelo de produção artística e de "tradução" do mundo. Entretanto, outros modos de conceber o teatro e a representação vêm sendo arregimentados, pautados na experiência e no fluxo individual, trata-se de um certo retorno ao modo ritualístico - esboçado por Vernant - presente entre os gregos, antes do surgimento das cidades.

Diante disso, noto que um dos nossos modos de mascaramento convencionalizado sobre nossa invenção do mundo estava justamente pautado pela própria noção de representação (dizer que se representa algo é supor que há algo inato a ser representado - pressuposto de um mundo dado). Contudo, perante as formas de produção de teatro, aposto em uma experiência social que indica a presença de um modo de encarar a arte, não mais pelo mascaramento ou pela convenção, mas sim pela própria diferenciação dos elementos. Quanto mais se diferencia e se inventa, para além da realidade - que deixa de ser uma questão -, mais próximo está de se fazer a arte que se quer. Há algo de estranho no reino da Dinamarca (e em outros também) cabe a nós tentar estudá-los.

\section{The invention of representation: a brief re- flection about the notion of representation}

abstract The notion of representation is an important subject to anthropology. I intend to contribute towards the discussion of the subject using insights arising from different areas, and attempt to establish a dialogue between all of them. The theatrical theory, Hellenistic historiography and contemporary anthropology are the major areas that serve as themes for reflection. In the contemporary theater theory we see a debate between essayists who seek to think the plays not as mimetic representation of reality, but as a scenic experience. My approach takes into consideration some historians, more specifically two Hellenists, to reflect on the modes of representation in the Greek world, and from them, understand what these modes are saying about us Westerners. Finally, I use Roy Wagner's theory to twist the meanings of representation and to reflect on it through other terms.

keywords Representation. Anthropology. Theatrical Theory. History. Social Experience.

\section{Notas}

1. Strathern utiliza o termo em diversos textos seus como em Parts and wholes: refiguring relationships in a post-plural world. In: KUPER, A. (Ed). Conceptualizing Society. London: Routledge, 1992. E discute a noçáo de Ocidente, brevemente em The limits of auto-an- 
thropology. In: JACKSON, A. (Ed.). Anthropology at Home. London: Tavistock Publications, 1987.

2. "A personalidade é uma preocupação da Cultura de classe média urbana que Schneider descreveu e analisou em seus estudos do parentesco norte-americano, e que ele distingue dos mundos interpretativos do parentesco das classes alta e baixa. A cultura fornece para todos os norte-americanos um conjunto comum de formas simbólicas e acionais, para além daquelas de suas orientaçóes particulares (...) e sustenta o arcabouço da vida pública. (...) A personalidade é um 'eu' atuante, uma individualidade deliberada incitada e motivada por uma Cultura precipitada” (Wagner, 2010, p.133-5).

3. A título de esclarecimento, o teatro dramático realista busca produzir uma peça absoluta; cujo autor está ausente; o público, também ausente, assiste a peça calado; o palco é distante e geralmente deve conter tudo aquilo que se assemelha à realidade; o ator deve unir-se à personagem, constituindo um único ser; o drama é compreendido como primário "ele não é a representação (secundária) de algo (primário), mas se apresenta a si mesmo, é ele mesmo" (Szondi, 2001, p.31-2). Alguns dramaturgos podem ser incluídos nessa categoria como Tchekhov, Ibsen e Gorki.

4. Valho-me da noção de campo presente em Pierre Bourdieu $(2005 ;$ 2009)

5. "Le statut du thêâtre est, de part en part, contradictoire. C'est une évidence qu'on perd souvent de vue. Fondé sur la 'mimesis', le thêâtre fait de l'action une illusion et transforme, parfois, l'illusion en action".

6. Para saber mais: Gassner, 2010.

7. A noção de contexto, como a de desmascaramento, em Roy Wagner será melhor detalhada adiante. Para Puchner os três autores que realizam tal crítica são Friedrich Nietzsche, Walter Benjamin e Michael Fried.

9. "What they [os críticos anti-teatrais] tend to object to is a particular form of mimesis at work in the theater, a mimesis caused by the theater's uneasy position between the performing and the mimetic arts. As a performing art like music or ballet, the theater depends on the artistry of live human performers on stage. As a mimetic art like painting or cinema, however, it must utilize these human performers as signifying material in the service of a mimetic project. Once the nature of mimesis is subject to scrutiny and attacks, as it is in modernism, this double affiliation on the theater becomes a problem because, unlike painting or cinema, the theater remains tied to human performers, no matter how estranged their acting might be".
10. Richard Wagner é aquele que serve de opositor aos autores que tentam se distanciar da representação. Encarado como um compositor que buscava produzir a "obra de arte total", seria o "grande responsável" pela confusão entre realidade e arte.

11. Utilizo aqui a publicação mais recente, presente em: FÉRAL, Josette. Theatricality: the specificity of theatrical language. Substance 98/99, vol.31, no 2 e 3, 2002.

12. Valho-me aqui da versão do texto de 1997 , presente em: FÉRAL, Josette. Performance and Theatricality: the subject demystified. In: MURRAY, T. Mimesis, masochism \& mime. The politics of theatricality in contemporary French thought. Ann Arbor: The Univesity of Michigan Press, 1997.

13. Evidente que ainda há diversas peças teatrais que se organizam de acordo com aquela produção engajada na representação mimética. Entretanto, estou interessado em apresentar essas novas práticas teatrais que surgem de grupos experimentais e que indicam outros modos de produção teatral.

14. Estou em diálogo com o artigo intitulado The limits of auto-anthropology, de 1987.

15. Destaco que a noção de representação defendida por Vernant é específica. Ao invés de associar a representação como um modo exclusivo de simulacro, Vernant entende representação como uma operaçáo mental de associação, que pode indicar uma relação ritual ou figurada.

16. Herótodo foi tido como o "primeiro" a rivalizar com as narrativas da epopeia que misturavam o mítico ao real, sua intenção, pelo contrário, se apoiava na tentativa de "conservar" a história por escrito, preocupado em pensar a história e a memória, tentou instituir uma "ciência" da história.

17. Destaco que Clifford Geertz (2009) e James Clifford (2008) possuem, cada um, livros que tratam deste tema de modo mais detalhado.

18. Se para os pós-modernos todas as ficçốes são invençôes (no sentido de "invencionice") em Roy Wagner as ficções são invençôes ou criaçôes simbólicas que não se equivalem.

19. "A invenção muda as coisas, e a convenção decompôe essas mudanças em um mundo reconhecível." (Wagner, Op. cit., p.98)

20. O diagnóstico de Latour (2009) é semelhante, quanto mais nos proibimos de pensar em híbridos mais seu cruzamento se torna possível, começamos a nos deparar com formas variadas de vivencias as experiências. 


\section{Referências bibliográficas}

BAXANDALL, Michael. O Olhar Renascente: pintura e experiência social na Itália da Renascença. Tradução de Maria Cecília P. da R. Almeida. Rio de Janeiro: Paz e Terra, [1972] 1991.

BOURDIEU, Pierre. "O mercado de bens simbólicos". In: A economia das trocas simbólicas. Introdução, organização e seleção Sergio Miceli. 6. ed. São Paulo: Perspectiva, 2005. p.89-181

. O Poder Simbólico. Tradução de Fernando Tomaz. 12. ed. Rio de Janeiro: Bertrand Brasil, [1989] 2009.

CLIFFORD, James. A experiência etnográfica: antropologia e literatura no século XX. Organização de José Reginaldo Santos Gonçalves. Tradução de Patrícia Farias. 3. ed. Rio de Janeiro: Editora UFRJ, [1994] 2008.

DORT, Bernard. La représentation émancipée. Paris: Actes Sud, 1988.

FÉRAL, Josette. Theatricality: the specificity of theatrical language. Substance 98/99, vol.31, no 2 e 3, 2002.

. "Performance and Theatricality: the subject demystified”. In: MURRAY, T. Mimesis, masochism \& mime. The politics of theatricality in contemporary French thought. Ann Arbor: The Univesity of Michigan Press. 1997.

FERNANDES, Silvia. Teatralidades Contemporâneas. São Paulo: Perspectiva; FAPESP, 2010.

GASSNER, John. Mestres do Teatro I. Tradução de Alberto Guzik e Jacó Guinsburg. 4. ed. São Paulo: Editora Perspectiva, [1974] 2010.

GEERTZ, Clifford. Obras e Vidas: o antropólogo como autor. Tradução de Vera Ribeiro. 3. ed. Rio de Janeiro: Editora UFRJ, [1988] 2009.
HARTOG, François. O espelho de Herótodo: Ensaio sobre a representação do outro. Tradução de Janyntho Lins Brandão. Belo Horizonte: Editora UFMG, [1980] 1999.

LATOUR, Bruno. Jamais fomos modernos: ensaio de antropologia simétrica. Tradução de Carlos Irineu da Costa. 2. ed. São Paulo: Ed. 34, [1991] 2009.

PROGRAMA teatral da peça Quartett. Texto: Heiner Müller, direção: Robert Wilson, produção: Odéon-Théâtre de l'Europe, La Comédie de Geneve, Théâtre Du Gymnase/Marseille. Realização no Brasil: SESC/SP, 2009

PUCHNER, Martin. Stage fright. Modernism, anti-theatricality \& drama. Baltimore and London: The Johns Hopkins University Press, 2002.

SZONDI, Peter. Teoria do drama moderno (1880-1950). Tradução de Luiz Sérgio Repa. São Paulo: Cosac Naify, [1965] 2001.

STRATHERN, Marilyn. "The limits of Auto-Anthropology”. In: JACKSON, A. (Ed.). Anthropology at Home. London: Tavistock Publications, 1987.

"Parts and wholes: refiguring relationships in a post-plural world”. In: KUPER, A. (Ed). Conceptualizing Society. London: Routledge, 1992.

VERNANT, Jean-Pierre. "Da presentificação do invisível à imitação da aparência”. In: Entre mito e política. Tradução de Cristiana Murachco. 2. ed. 1. reimpr. São Paulo: EDUSP, [1996] 2009, p.295-307.

VIVEIROS DE CASTRO, Eduardo. O nativo relativo. Mana, 8(1), 2002, p.113-148.

WAGNER, Roy. A invenção da cultura. Tradução de Marcela Coelho de Souza e Alexandre Morales. São Paulo: Cosac Naify, [1981] 2010.

\section{autor \\ Bernardo Fonseca Machado \\ Mestrando em Antropologia Social / USP}

Recebido em 14/03/2011

Aceito para publicação em 26/09/2011 